\title{
Strategi Kebijakan Pemerintah Venezuela di Tengah Krisis
}

Nuryanti ${ }^{1}$, Salsabila ${ }^{2}$

uryantiedisuryansyah@gmail.com¹, ilasalsabilaaaa@gmail.com²

Program Studi Hubungan Internasional, Universitas Muhammadiyah Malang, Gedung

Kuliah Bersama (GKB) I Jl. Raya Tlogomas No.246 Malang 65144, Jawa Timur,

Indonesia

\begin{abstract}
Abstrak
Pada era presiden Nicolas Maduro, Negara Venezuela berada dalam kondisi krisis. Krisis tersebut diantaranya sosial dan politik yang buruk. Salah satu kondisi paling buruknya adalah krisis ekonomi. Keadaan ini berimbas pada tingkat kepercayaan masyarakat terhadap presiden sangat rendah. Kebijakan yang dianggap kurang efektif dan represif dari Presiden Nicolas Maduro telah mendorong gejolak politik yang memperparah situasi dalam negeri. Dengan demikian, penulis tertarik untuk menjelaskan upaya pemerintah Venezuela dalam mengahadapi krisis tersebut. Penulis menggunakan metode penelitian deskriptif kualitatif dan teknik pengumpulan data berdasarkan studi pustaka. Sumber data berasal dari literatur hasil publikasi penelitian para akademisi dan pakar tentang politik Venezuela dan krisis ekonomi Amerika Latin. Penulis mencatat beberapa tindakan pemerintah Venezuela dalam menghadapi krisis ekonomi diantaranya: (1) kebijakan diverifikasi ekonomi; (2) diplomasi bantuan luar negeri kepada china; (3) stabilisasi harga pangan: (4) penguatan pelayanan kesehatan masyarakat; dan (5) penguatan kerjasama regional dengan organisasi di kawasan Amerika Latin.
\end{abstract}

Kata Kunci: Amerika Latin, Kebijakan, Krisis Ekonomi, Venezuela

\begin{abstract}
In the era of president Nicolas Maduro, the Venezuela faced economic crisis. It affects to social and economic decline. The govenment is in the chellenge of public trust and political instablity. The Maduro performance perceived as less effective and repressive that lead to the society questioning about government capacity to solve the problems. Thus, the authors are interested in explaining the efforts of the Venezuelan government in dealing with the crisis. The author uses descriptive qualitative research methods and data collection techniques based on literature study. The data source comes from the literature published by scholars and experts on Venezuelan politics and the Latin American economic crisis. The author notes several actions of the Venezuelan government in dealing with the economic crisis including: (1) economic policies reform; (2) diplomacy of foreign aid to China; (3) food price stabilization: (4) strengthening public health services; and (5) strengthening regional cooperation with organizations in the Latin American region.
\end{abstract}

Keywords: Economic crisis, Latin America, Policy, Venezuela

\section{Pendahuluan}

Krisis ekonomi telah menjadi fenomena umum sepanjang sejarah ekonomi modern umat manusia. Sejak depresi besar 1929, dunia telah menyaksikan ratusan krisis seperti itu dan frekuensi krisis meningkat dari waktu ke waktu (Das, N.R, Debnath, \& S.C,

\footnotetext{
${ }^{1}$ Korespondensi:
} 
2012). Krisis ekonomi merupakan suatu keadaan atau situasi dimana sebuah negara mengalami kesulitan terhadap keuangannya yang dapat disebabkan oleh berbagai hal. Dimana hal tersebut dapat memicu terjadinya inflasi. Serta hal lain yang menjadi dampak terbesar dari terjadinya krisis adalah dimana berpengaruh terhadap pendapatan atau pendapatan domestik bruto (PDB) negaranya (Siregar, 2010).

Kerawanan perekonomian terjadi karena unsur-unsur yang pada dasarnya bersifat internal dan eskternal seperti kebijaksanaan makro yang tidak sustainable, lemahnya atau hilangnya kepercayaan terhadap mata uang dan lembaga keuangan dan ketidakstabilan politik, kondisi keuangan global yang berubah, misalignment dari nilai tukar mata uang dunia (dollar dengan yen) (Karmeli \& Fatimah, 2008). Laporan IMF, World Economic Outlook dalam Karmeli \& Fatimah, (2008) bahwa Krisis itu sendiri yang baru digolongkan menjadi berbagai jenis, yaitu (1). Currency crisis, (2). Banking crisis, (3). Systemic financial crisis dan (4). Foreign debt crisis. Berdasarkan definisi tersebut maka krisis ekonomi merupakan kesulitan terhadap keuangannya yang dapat disebabkan oleh kebijakan makro yang tidak sustainable, lemahnya atau hilangnya kepercayaan terhadap mata uang dan lembaga keuangan dan ketidakstabilan politik, kondisi keuangan global yang berubah, misalignment dari nilai tukar mata uang dunia. Salah satu Negara yang mengalami krisis ekonomi hebat adalah Negara Venezuela yang tergabung dalam Negara kawasan Amerika latin.

Venezuela merupakan Negara dikawasan amerika latin yang sedang mengalami krisis ekonomi. BBC melaporkan bahwa dampak pertama pelemahan dan krisis ekonomi negara ini adalah tingkat inflasi yang terus meningkat. Menurut sebuah studi oleh Majelis Nasional yang dikendalikan oleh pihak oposisi Negara ini bahwa tingkat inflasi tahunan negara mencapai 1.300.000\% dalam 12 bulan hingga November 2018 sehingga menyebakan harga kebutuhan pokok naik rata-rata dua kali lipa setiap 19 hari (Al Hikam, 2019). Selain itu, nilai tukar mata uang bolivar juga terus melemah dari awalnya US\$ 1 untuk 200 bolivar pada tahun 2018, namun saat ini untuk US\$ 1 hanya dapat 1.600 bolivar (Al Hikam, 2019). Krisis yang dialami oleh Venezuela ini terjadi pada masa kepemimpinan presiden Maduro menerapkan sistem ekonomi yang bersifat ekonomi campuran yakni dilakukan dengan cara menerapkan penetapan harga terhadap kebutuhan bahan pokok yang dilakukan oleh pemerintah Venezuela (Bonita, 2017, p. 265).

Penetapan sistem ekonomi oleh pemerintah dengan harga terhadap bahan pokok makanan sangat murah sehingga mengakibatkan para produsen memilih untuk menjual barang mereka ke pasar gelap yang harganya jauh lebih mahal yaitu mencapai lima belas kali lipat harga yang ditetapkan oleh pemerintah venezuela sendiri. Hal tersebutlah kemudian yang dinilai menjadi sebab terjadinya kelangkaan bahan pangan di Venezuela yang menjadi cikal bakal krisis ekonomi di negara tersebut. 
Krisis ekonomi yang dialami oleh Negara Venezuela ini mengakibatkan kelaparan, penyakit menular, 2,3 juta orang meninggalkan dari tahun 2014 sampai bulan Juni 2018, dari 32,4 juta jumlah penduduk Venezuela, lebih 2,3 juta (7\%), telah mengungsi akibat krisis ekonomi dan politik (Nainggolan, 2018). Selain itu terjadi, sebagaimana data yang dikemukaka oleh PBB bahwa gelombang migrasi yang terjadi di beberapa negara tetangga Venezuela telah dimulai sejak tahun 2015 dan pada tahun 2018, tercatat sekitar 2,3 juta Rakyat Venezuela yang telah meninggalkan Venezuela untuk memperoleh penghidupan yang lebih baik dan menghindari krisis ekonomi yang terjadi di Venezuela tersebut (Modolo \& Texido, 2018). Selain disebabkan oleh faktor tersebut, krisis di negara Venezuela juga disebabkan oleh langkanya harga minyak dunia sehingga berdampak pada pendapatan nasional Venezuela yang hampir seluruhnya bergantung pada industri perminyakan di negara tersebut. Sehingga, satu tahun setelah terpilihnya Maduro, yakni tahun 2014, Venezuela mengalami suatu keadaan Krisis ekonomi (Bonita, 2017).

Kebijakan ekonomi populis yang tidak mempertimbangkan pengelolaan negara yang baik sehingga membawa Venezuela di bawah Hugo Chavez gagal membawa Venezuela yang kaya minyak ke arah pemerataan kesejahteraan. Ketergantungan pada ekspor minyak, utang luar negeri dan komoditi impor telah memperburuk kondisi ekonomi domestik. Jatuhnya harga minyak dan nilai tukar Bolivars serta meningkatnya inflasi secara ekstrim membuat ekonomi nasional benar-benar runtuh. Kehadiran Nicolas Maduro yang dipaksakan lewat pemilu yang kontroversial tidak banyak membantu, sehingga rakyat Venezuela eksodus ke mancanegara (Nainggolan, 2018). Hal tersebutlah yang kemudian sekarang tengah dihadapi oleh Venezuela. Krisis tersebut berkembang dengan meningkatnya berbagai masalah di Republik Bolivarian Venezuela, seperti peningkatan pengangguran, krisis keuangan dan kurangnya makanan pokok, kebersihan dan produk kesehatan. Kekurangan di Venezuela dihasilkan dari salah urus ekonomi pemerintah (Hortiguera, 2018, p. 3). Terdapat beberapa negara yang tercatat sebagai negara tujuan para imigran asal Venezuela. Beberapa diantaranya tersebut seperti Spanyol, Italia, Republik Dominika, Columbia, Costa Rica, Mexico, Panama, Ekuador, Peru, Uruguay, Argentina, Chile, Brazil, Trinidad and Tobago, Portugal, Canada hingga Amerika Serikat.

Negara tujuan utama Venezuela adalah Kolombia (600.000), Amerika Serikat (290.000) dan Spanyol (208.000). jika melihat dari segi alasan mengapa rakyat Venezuela memilih beberapa negara tersebut adalah melihat dari respon negara-negara tersebut terhadap imigran seperti misalnya Amerika Serikat menyediakan peluang pasar tenaga kerja untuk Venezuela yang terampil dan profesional; Spanyol menyediakan saluran hukum kewarganegaraan untuk Venezuela dengan nenek moyang Spanyol (Modolo \& Texido, 2018). Selanjutnya Kolombia, adanya kebijakan Kolombia seperti kebijakan tentang keluarga dan tempat tinggal, memfasilitasi imigrasi Venezuela. Negara-negara ini bersamasama menyumbang sekitar 68 persen dari satu setengah juta rakyat Venezuela di luar negeri. 
Menarik juga untuk dicatat bahwa di Spanyol, jumlah perempuan (113.292) lebih besar daripada pria (95.041). Selain itu, lebih dari 60 persen (127.825) orang Venezuela di Spanyol memiliki kewarganegaraan Spanyol, terkait dengan emigrasi Spanyol sebelumnya ke Venezuela (Modolo \& Texido, 2018).

Selanjutnya, melihat Respon Chile terhadap imigran, masyarakat Venezuela memilih Chile salah satu alasannya adalah Chili memiliki upah minimum tertinggi ketiga di Amerika Latin serta proses imigrasi yang relatif mudah, menjadikannya tempat yang menarik bagi Venezuela untuk mencari suaka. Terlepas dari kondisi Chili yang menjanjikan bagi para pengungsi, seperti halnya di setiap negara lain, rakyat Venezuela harus memulai dari awal tanpa pekerjaan, sedikit uang, dan berharap bahwa mereka akan segera dapat kembali ke Venezuela (Bierly, 2018). Dengan demikian, berdasarkan latar belakang tersebut penulis akan menganalisis upaya pemerintah Venezuela dalam menghadapi krisis ekonomi pada era presiden Nicolas Maduro.

\section{Tinjauan Pustaka}

\section{Definisi Krisis Ekonomi}

Krisis ekonomi telah menjadi fenomena umum sepanjang sejarah ekonomi modern umat manusia. Sejak depresi besar 1929, dunia telah menyaksikan ratusan krisis seperti itu dan frekuensi krisis meningkat dari waktu ke waktu (Das et al., 2012). Krisis ekonomi merupakan suatu keadaan atau situasi dimana sebuah negara mengalami kesulitan terhadap keuangannya yang dapat disebabkan oleh berbagai hal. Dimana hal tersebut dapat memicu terjadinya inflasi. Serta hal lain yang menjadi dampak terbesar dari terjadinya krisis adalah dimana berpengaruh terhadap pendapatan atau pendapatan domestik bruto (PDB) negaranya (Siregar, 2010). Inflasi menjadi faktor utama sebagai penyebab terjadinya krisis pada pendapatan Negara sehingga ini menjadi masalah dalam keuangan suatu Negara.

Menurut UNCTAD (2008a) dalam Das, Kumar, Debnath, \& Mandal, (2012) terdapat sebagian besar dari negara mulai dengan proses terburu-buru reformasi pada sektor keuangan, yang tidak hanya menciptakan kekosongan dalam hal peraturan tetapi juga memburuk fundamental ekonomi dasar meskipun arus masuk besar modal asing dan akhirnya berakhir dengan perubahan dalam harapan investor dan kekacauan selanjutnya di pasar keuangan. Selain itu, bahwa kerawanan perekonomian terjadi karena unsur-unsur yang pada dasarnya bersifat internal dan eskternal seperti kebijaksanaan makro yang tidak sustainable, lemahnya atau hilangnya kepercayaan terhadap mata uang dan lembaga keuangan dan ketidakstabilan politik, kondisi keuangan global yang berubah, misalignment dari nilai tukar mata uang dunia (dollar dengan yen) (Karmeli \& Fatimah, 2008). Laporan IMF, World Economic Outlook dalam Karmeli \& Fatimah, (2008) bahwa Krisis itu sendiri yang baru digolongkan menjadi berbagai jenis, yaitu (1). Currency crisis, (2). Banking crisis, (3). Systemic financial crisis dan (4). Foreign debt crisis. 
Berdasarkan definisi di atas maka krisis ekonomi yang dihadapi pemerintah Venezuela merupakan kesulitan terhadap sektor keuangan yang disebabkan oleh kebijakan ekonomi makro yang tidak berkelanjutan, lemahnya atau hilangnya kepercayaan terhadap mata uang dan lembaga keuangan serta ketidakstabilan politik, di tengah kondisi keuangan global yang berubah, dan tekanan dari nilai tukar mata uang dunia.

\section{Amerika Latin dan Mercosur}

Kawasan Amerika Latin merujuk pada empat sub kategori definisi terkait negara kawasan Amerika Latin antara lain yaitu; Pertama, negara negara yang berada di wilayah Amerika yang menggunakan bahasa Spanyol, Portugis ataupun Prancis yang diantaranya terdiri dari: Meksiko, sebagian besar di Amerika Tengah dan selatan, Karibia, Kuba, Republik dominika, Haiti, dan Poerte Riko., Kedua, yang dikatakan Amerika Latin yaitu semua bagian dari Amerika yang pernah menjadi bagian dari kekaisaran Portugis, Spanyol, dan Prancis, dimana Amerika Latin sangat berbatasan dengan wilayah Ibero Amerika ketika mengeluarkan wilayah minoritas berbahasa Prancis.

Ketiga, adalah istilah yang digunakan dengan lebih meluas. Yang merujuk pada semua Amerika di Amerika serikat yang termasuk Guiana, Anglophone Karibia, dan Belize, Karibian Francophone dan Karibia Belanda (the world bank, 2019). Keempat, mendefinisikan pada penekanan pada sejarah sosial ekonomi yang sama di wilayah tersebut yang ditandai dengan adanya peristiwa kolonialisme pada aspek budayanya. Adapun beberapa negara Amerika Latin yaitu: Argentina, Bolivia, Brazil, Chile, Columbia, Costarica, Cuba, Republik Dominika, Ekuador, El-savador, French Guiana, Guadeloupe, Guatemala, dan Haiti.

Mercosur merupakan singkatan dari Mercando Comun Del Sur, merupakan salah satu bentuk kerjasama regional berupa blok perdagangan di kawasan Amerika Latin. Karena Mercosur dalam keanggotaannya berisi negara-negara Amerika Latin. Mercosur terdiri dari lima negara anggota yang diantaranya yaitu Brazil, Argentina, Paraguay, Uruguay, dan Venezuela. Adapun tujuan dari dibentuknya Mercosur sebagai blok perdagangan yaitu untuk memudahkan negara anggotanya di sektor perekonomian terkait pergerakan modal, barang, dan jasa yang akan memberikan dampak terhadap kesejahteraan perekonomian bagi kawasan Amerika Latin sendiri (Raga, 2018).

\section{Definisi Regionalisme}

Istilah regionalisme berasal dari kata 'regional' ditambah 'isme'. Region dalam perspektif hubungan internasional merupakan unit terkecil dari suatu negara yaitunationstate. Sedangkan regional merupakan dua atau lebih negara (nation-state) yang letaknya secara geografis berdekatan. Berdasarkan pengertian tersebut maka regionalisme dapat dimaknai secara sederhana sebagai suatu kerjasama regional. Sementara, menurut 
Mansbaach, region (kawasan) adalah "pengelompokan regional diidentifikasi dari basis kedekatan geografis, budaya, perdagangan dan saling ketergantungan ekonomi yang saling menguntungkan, komunikasi serta keikut sertaan dalam organisasi internasional. T. May Rudi (1997:22) menegaskan bahwa, hal terpenting dalam kajian regionalisme adalah meninjau derajat keeratan (level of cohesion), struktur dalam pelaksanaan peran atau percaturan politik (structure of relations) dalam suatu kawasan, serta rasa kebersamaan yang mewarnai tumbuhnya kerjasama regional tersebut. Sehingga dapat diumpamakan bahwa kawasan itu layaknya wadah dan regionalisme adalah isinya. Atau jika kawasan itu adalah jasad manusia, regionalisme adalah ruhnya (Nuraeni, Silvya, Sudirman, \& Adinugraha, 2010, p. 1).

Konsep ini kemudian dapat menjelaskan karakteristik pola hubungan negaranegara di kawasan Amerika Latin. Venezuela dalam percaturan politik regional dipengaruhi oleh kepentingan negara-negara dalam satu kawasan, dimana masyarakatnya memiliki kesamaan etnis maupun budaya.

\section{Metode Penelitian}

Metode deskriptif kualitatif yang digunakan dalam penelitian ini bertujuan untuk mendeskripsikan fenomena yang terjadi pada suatu obyek penelitian. Penulis berupaya menjelaskan upaya pemerintah Venezuela dalam menghadapi krisis ekonomi di masa kepemimpinan presiden Nicolas Maduro. Teknik pengumpulan data yang digunakan dalam penelitian ini adalah studi literatur. Sumber data yang digunakan oleh peneliti adalah publikasi hasil penelitian para akademisi dan para ahli yang berhubungan dengan krisis ekonomi Venezuela dalam bentuk daring maupun cetak. Laporan pemerintah Venezuela dan organisasi internasional serta media massa digunakan untuk mendukung argumentasi penulis. Teknik analisis dilakukan dengan membaca artikel hasil penelitian, mencerrmati, dan mencatat hal-hal penting yang membuktikan argumentasi penelitian. Analisis ditujukan untuk mengungkapkan berbagai teori-teori yang relevan dengan permasalahan.

\section{Hasil dan Pembahasan}

\section{Strategi Kebijakan Pemerintah Venezuela}

Upaya yang dilakukan pemerintah dalam mengatasi krisis ekonomi yaitu pemerintah kini fokus melakukan diverifikasi ekonomi dengan tidak hanya mengandalkan komoditas minyak saja tetapi sedikitnya terdapat 15 motor penggerak lainnya yang ikut dijadikan penggerak roda perekonomian Venezuela. Beberapa motor penggerak ekonomi Venezuela antara lain yaitu farmasi, industri, petrokimia, pariwisata, telekomunikasi, hingga pertanian. Kemudian perkebunan Venezuela juga tidak kalah unggul dimana antara lain yaitu cokelat, kopi, tebu, hingga tembakau. Beberapa hasil kebun buah pun melimpah di negara Venezuela tersebut mulai dari alpukat, pisang, pepaya, jeruk, nanas, hingga 
anggur. Setelah adanya situasi krisis di Venezuela pemerintah memutuskan untuk melakukan diverifikasi ekonomi (Chandra, 2017).

Selain itu juga pemerintah Venezuela saat ini sedang berupaya kerasa untuk dapat mengembalikan stabilitas harga pangan di negaranya. Dimana pemerintah Venezuela sudah menyiapkan sejumlah strategi untuk mengatasi krisis ekonomi di negaranya, salah satunya dengan menggelontarkan sebagian besar anggaran negaranya bagi pemenuhan kebutuhan pangan. Kemudian juga pemerintah Nicolas Maduro akan mendongkrak volume produksi minyak bumi yang memegang menjadi andalan perekonomian Venezuela selama ini. langkah lainnya yaitu pemerintah Venezuela dengan mengembangkan mata uang virtual (Andreas, 2018).

Nicolas Maduro menerapkan kebijakan pelayanan kesehatan masyarakat yaitu Barrio Adentro. Kebijakan ini dinilai sebagai sebuah langkah untuk mengatasi krisis legitimasi terhadap dirinya. Untuk meningkatkan legitimasinya melalui kebijakan Barrio Adentro, Nicolas Maduro memanfaatkan dua level politik. Pada level internasional, Nicolas Maduro memanfaatkan kerjasama dengan Kuba, China, Palestina, India dan ALBA untuk menyediakan sumberdaya bagi berlangsungnya Barrio Adentro. Sedangkan Pada level domestik, Nicolas Maduro melakukan peningkatan kualitas pelayanan kesehatan Barrio Adentro dengan melakukan perluasan wilayah cakupan Barrio Adentro, pembangunan fasilitas kesehatan dan pengadaan program distribusi obat-obatan untuk menunjukkan Barrio Adentro berjalan dengan baik (Mirah Satria Alamsyah \& Mohtar Mas'oed, 2018).

Presiden Venezuela Nicolas Maduro meminta bantuan China untuk mengatasi masalah ekonominya. Nicolas Maduro dalam hal ini mengunjungi Beijing, dimana dirinya mengadakan perundingan dengan Presiden Xi Jinping dan Perdana Menteri Li Keqiang dan juga terkait dengan kesepakatan di bidang energi, perdagangan dan keuangan. Tepatnya pada 14 September Venezuela menjalani hubungan bersama dengan China dalam mengatasi krisis ekonomi yang terjadi. Dimana kesepakatan ditandatangani yang meratifikasi kesepakatan pembangunan bersama, penanaman modal, ratusan juta investasi untuk merealisasikan pembangunan perusahaan bersama antara kedua negara (BBC, 2018b).

Menghadapi era globalisasi yang mendominasi serta perdagangan bebas didalamnya, banyak negara-negara seregional yang menciptakan suatu organisasi bentukan guna untuk menangkal efek buruk yang akan terjadi dengan datangnya gelombang dasyat globalisasi terutama globalisasi ekonomi. Dalam regional Amerika Latin terdapat beberapa organisasi regional dalam bidang ekonomi yang dibentuk sebagai respon atas globalisasi dan perdagangan bebas yang telah dilakukan oleh negara-negara maju. Organisasiorganisasi regional tersebut juga diharapkan dapat mendorong integrasi di kawasan Amerika Latin itu sendiri (Azizah, 2014). 
Adapun organisasi organisasi tersebut antara lain, (1) Mercosur (Mercado Comun Del Sur) yang merupakan salah satu organisasi regional di Amerika Latin yang didirikan oleh Argentina, Brazil, Paraguay dan Uruguay melalui Treaty of Asunction pada bulan Maret tahun 1991. Tujuan dari pembentukan Mercosur adalah untuk memajukan perdamaian dan kestabilan serta menguatkan kerjasama internal dan kerjasama internasional. Adanya regionalisasi dalam perekonomian internasional negara-negara di Amerika Latin ini menunjukkan adanya liberalisasi perdagangan antara negara-negara anggota Mercosur. Pada dasarnya Mercosur merupakan sebuah perjanjian dengan tujuan akhir yang ambisius untuk membentuk integrasi perekonomian di kawasan Amerika Latin (Azizah, 2014).

Dengan adanya Mercosur juga kemudian memicu trade creation dan trade diversion, dimana Mercosur memiliki kecenderungan hanya berdagang manufaktur untuk sesama anggotanya karena tarif dari negara anggota terhadap non anggota, hal ini menghilangkan keinginan konsumen untuk membeli dan mengakses teknologi dari negara maju. Namun, perlu dipahami bahwa integrasi terhadap kelompok regional dapat menghilangkan potensi untuk mendapatkan integrasi dengan dunia luar dan menghilangkan kesempatan mendapat transfer teknologi yang seharusnya dapat menambah keuntungan negara tersebut, dengan melihat anggota Mercosur masih terdiri dari negara - negara berkembang (Azizah, 2014).

Meningkatnya regionalisme baru di kawasan Amerika Latin tidak terlepas dari pengaruh pihak eksternal terutama Amerika Serikat. Perubahan dalam politik luar negeri Amerika Serikat mempengaruhi regionalisme di Amerika Latin dikarenakan posisi Amerika Serikat sebagai hegemon baik di regional Amerika maupun dalam lingkup global. Amerika Serikat mengubah politik luar negeri tradisional yang dianutnya dan mengadopsi tiga jalur kebijakan politik dan komersial yaitu kombinasi strategis dan pragmatis dari multilateralisme yang berarti hubungan internasional yang menunjukkan kerjasama antara beberapa negara, regionalisme dan unilateralisme. Hal inilah yang mendorong masuknya liberalisme ke wilayah Amerika Latin dan menimbulkan kesadaran regional negara-negara dalam wilayah tersebut

(2) ALBA (Agreement for the Application of the Bolivarian Alternative of the Americas and the People's Trade Agreements) sebagai kerjasama alternatif, dimana pada tahun 2004, Venezuela dan Kuba memprakarsai kerjasama regional bersama dengan ALBA yang dideklarasikan di Ibu Kota Kuba, Havana pada tanggal 28 April 2005. Dimana asumsi dasarnya adalah kecenderungan negara-negara yang memanfatkan rezim atau institusi internasional untuk mencapai kepentingan negara tersebut. Maka negara-negara tersebut kemudian membentuk rezim selama hal tersebut masih bisa memenuhi kepentingan mereka. Chavez dan Evo Morales yang berkepentingan untuk tetap vokal terhadap Amerika Serikat tentu saja akan melihat kepentingan ini akan lebih baik jika didukung oleh negara-negara lain (Ma'arif, 2012). 
Adapun prospek kerjasama regional ALBA juga bekerja pada tiga ruang yang dimana pada ruang ide, negara-negara anggota percaya perlunya prinsip-prinsip saling melengkapi, solidaritas dan kerjasama untuk mencapai kemakmuran dan pemerataan pembangunan regional. Pada ruang institusi, ide ini kemudian diintegrasikan dalam ALBA. Melalui pembagian struktur organisasi ALBA, Dewan Politik. (Political Counci) dan Dewan Ekonomi (Economic Counci) memastikan upaya menandingi hegemoni neoliberalisme kemudian dapat terfasilitasi dengan adanya koordinasi kebijakan ekonomi politik diantara negara-negara anggota. Melalui Dewan Sosial (Social Counci) dan Dewan Gerakan Sosial (Social Movements Counci) dalam struktur organisasi menjadikan ALBA sebagai sebuah organisasi kerjasama regional yang didalamnya rakyat diikutsertakan dalam upaya mencapai kemakmuran dan pemerataan pembangunan (Azizah, 2014).

Kemudian juga negara-negara Amerika Latin menyerukan dunia internasional untuk memberikan bantuan kepada jutaan pengungsi Venezuela yang melarikan diri dari negaranya karena krisis ekonomi. Dimanaya sebanyak 11 negara yang terdiri dari Argentina, Brasil, Ekuador, Kosta Rika, Kolombia, Cile, Meksiko, Panama, Paraguay, Peru, dan Uruguay juga menandatangani deklarasi di ibu Kota Ekuador Quito yang menyerukan perlunya peningkatan perhatian untuk mengatasi eksodus warga Venezuela. Delegasi negara-negara tersebut kemudian bertemu di Quito untuk membentuk tim teknis guna untuk mengatasi krisis pengungsi Venezuela. Dimana mereka juga menyerukan peningkatan bantuan bagi warga Venezuela oleh negara-negara Amerika Latin dan dunia internasional. Selain itu, negara Amerika Latin juga meminta bantuan Perserikatan BangsaBangsa (BBC, 2018a).

\section{Kesimpulan}

Sebagai organisasi regional yang beranggotakan negara-negara Amerika Latin termasuik di dalamnya Venezuela, krisis yang terjadi di Venezuela merupakan permasalahan tersendiri yang dihadapi oleh Mercosuir. Venezuela secara resmi telah bergabung dengan Mercusor sejak tahun 2012 dan menjadi bagian dari Organisasi Regional tersebut. Terhadap kasus tersebut, Mercosur kemudian merespon dengan menghimbau Presiden Nicolas Maduro untuk segera melakukan pemilihan umum ulang dan menganut sistem pemerintahan demokrasi untuk dapat menyelesaikan masalah krisis ekonomi yang juga bermula dari adanya pemerintahan otoriter di Venezuela tersebut (Aljazeera , 2016).

Adapun status Venezuela sendiri sebagai anggota dari Mercosur berada dalam ujung tanduk dengan adanya rencana penangguhan keanggotannya karena berbenturan dengan prinsip-prinsip demokrasiu yang dimiliki oloeh organisasi tersebut yang juga menginginkan anggotanya untuk dapat menjalankan prinsip tersebut. Pemerintahan Presiden Maduro yang dinilai diktator-otoriter di Venezuela dinilai membawa dampak 
terjadinya krisis ekonomi di negara yang memiliki penghasilan minyak terbesar tersebut yang pada kenyataan seharusnya mustahil mengalami krisis ekonomi jika pemerintahan dijalankan dengan prinsip demokrasi yang telah jauh sebelumnya ditawarkan oleh Mercosur (Aljazeera, 2016). Sehingga, anggota pendiri Mercosur yaitu Argentina, Brazil, Paraguay dan Uruguay membuat keputusan dengan sepakat untuk mencabut keanggotaan Venezuela di Mercosur.

Pada era presiden nicolas maduro, negara venezuela berada dalam kondisi krisis. Krisis tersebut diantaranya sosial dan politik yang buruk. Salah satu kondisi paling buruknya adalah krisis. Ekonomi keadaan ini berimbas pada legitimasi masyarakat terhadap nicolas maduro sangat rendah. Ada beberapa upaya yang dilakukan oleh negera venezuela sebagai negara kawasan amerika latin dalam menghadapi krisis ekonomi pada era presiden Nicolas Maduro diantaranya diverifikasi ekonomi meminta bantuan China; mengembalikan stabilitas harga pangan; menerapkan kebijakan pelayanan kesehatan masyarakat; venezuela membentuk kerjasama regional dengan bergabung pada organisasi di kawasan amerika latin.

Selanjutnya, dalam menjelaskan respon Mercosur sebagai organisasi di kawasan Amerika Latin terhadap krisis ekonomi yang melanda Venezuela, penulis melihat dengan kacamata saling ketergantungan diantara negara-negara kawasan. Dimana dengan bergabung dalam sebuah organisasi regional, maka permasalahan yang terjadi diantara masing-masing anggotanya akan dapat mempengaruhi negara anggota lainnya. Hal tersebutlah yang kemudian terjadi pada krisis ekonomi Venezuela yang dapat mempengaruhi keadaan negara-negara anggota Mercosur lainnya.

\section{Ucapan Terima kasih}

Ucapan terimakasih yang sebesar-besarnya penulis tunjukan kepada Ibu Demeiati Nur Kusumaningrum selaku pengampu mata kuliah HI Kawasan Amerika yang telah memberikan beberapa masukan dan saran untuk penulisan kami. Selain itu, ucapan terimakasih juga kami tujukan kepada teman-teman kelas HI Kawasan Amerika yang telah mendukung penulisan ini dengan memberi beberapa masukan maupun pertanyaan yang dapat menjadi bahan perbaikan tulisan kami.

\section{Daftar Pustaka}

Al Hikam, H. A. (2019). Venezuela Krisis, Ekonomi Masyarakat Kian Menyedihkan. Retrieved November 26, 2019, from https:/ / finance.detik.com/berita-ekonomibisnis/d-4402467/venezuela-krisis-ekonomi-masyarakat-kian-menyedihkan

Andreas, D. (2018). Kunjungi Jakarta, Bawahan Maduro Ungkap Cara Venezuela Atasi Krisis - Tirto.ID. Retrieved October 25, 2019, from https://tirto.id/kunjungijakarta-bawahan-maduro-ungkap-cara-venezuela-atasi-krisis-cWyo 
Azizah, S. (2014). Peran Common Market Amerika Latin/ Mercado Común del Sur (MERCOSUR) dalam Meningkatkan Perekonomian Brasil Melalui Kerjasama Ekonomi. Jom FISIP, 1(2), 1-15. Retrieved from https://jom.unri.ac.id/index.php/JOMFSIP/article/view/3340/3237

BBC. (2018a). Venezuela: Jumlah orang yang hijrah masih tergolong "normal." Retrieved October 25, 2019, from https://www.bbc.com/indonesia/dunia-45417197

BBC. (2018b). Venezuela Minta Bantuan China Untuk Mengatasi Masalah Ekonomi. Retrieved October 25, 2019, from https://www.bbc.com/indonesia/dunia45525670

Bierly, R. (2018). How Latin America is handling the Venezuelan Refugee Crisis | Panoramas. Retrieved October 25, 2019, from https://www.panoramas.pitt.edu/news-and-politics/how-latin-americahandling-venezuelan-refugee-crisis

Bonita, V. (2017). Pemberian Sanksi Executive Order Terhadap Pejabat Venezuela Masa Pemerintahan Maduro Oleh Amerika Serikat. EJournal Hubungan Internasional, 6(1), 265. Retrieved from https:// ejournal.hi.fisip-unmul.ac.id/site/?p=2502

Chandra, A. A. (2017). Langkah Venezuela Keluar dari Krisis Ekonomi. Retrieved October 29, 2019, from https://finance.detik.com/berita-ekonomi-bisnis/d3643505/langkah-venezuela-keluar-dari-krisis-ekonomi

Das, A., N.R, K., Debnath, B., \& S.C, M. (2012). Global Economic Crisis: Causes, Impact on Indian Economy, Agriculture and Fisheries. International Journal of Agriculture Sciences, 4(4), 221-226. https://doi.org/10.9735/0975-3710.4.4.221-226

Hortiguera, J. A. (2018). The Crisis in Venezuela. Retrieved November 12, 2019, from https://data.worldbank.org/region/latin-america-and-caribbean)

Karmeli, E., \& Fatimah, S. (2008). Krisis Ekonomi Indonesia. Journal of Indonesian Applied Economics, 2(2), 164-173.

Ma'arif, S. (2012). Neososialisme Kebijakan Ekonomi Politik (Pengalaman Venezuela Di Bawah Hugo Chavez). Jurnal Ilmiah Administrasi Publik Dan Pembangunan, 3(2), 114.

Mirah Satria Alamsyah, \& Mohtar Mas'oed. (2018). Upaya Nicolas Maduro Mengatasi Kemerosotan Legitimasi Melalui Kebijakan Barrio Adentro Pada Masa Krisis Venezuela. Departemen Ilmu Hubungan Internasional, Fakultas Ilmu Sosial Dan Ilmu Politik, Universitas Gadjah Mada.

Modolo, V., \& Texido, E. (2018). Latin America's response to Venezuelan emigration. Retrieved October 29, 2019, from Immigration and Emigration Statistic website: https://migrationdataportal.org/blog/latin-americas-response-venezuelanemigration

Nainggolan, P. P. (2018). Krisis Venezeula dam Migrasi Internasional. Bidang Hubungan 
Internasional Kajian Singkat Terhadap Isu Aktual Dan Strategis, 10(18), 7-12. Retrieved from http://berkas.dpr.go.id/puslit/files/info_singkat/Info SingkatX-18-II-P3DI-September-2018-160.pdf

Nuraeni, S., Silvya, D., Sudirman, A., \& Adinugraha, E. (2010). Regionalisme dalam Studi Hubungan Internasional. Yogyakarta: Pustaka Pelajar.

Raga, P. (2018). Dinamika Regionalisme Amerika Latin Tabun 1991-2018: Analisis Kegagalan Integrasi Mercando Comun Del Sur (Mercosur). Retrieved from https://dspace.uii.ac.id/bitstream/handle/123456789/9829/08 Naskah Publikasi.pdf?sequence $=10$ \&isAllowed $=\mathrm{y}$

Siregar, R. C. (2010). Resensi Buku Memahami Krisis oleh Tulus Tambunan. Retrieved October 29, 2019, from Definisi Krisis Ekonomi website: https://docs.google.com/document/d/1W03ZUd7EBNSXI6PzEjATSEZRj3FkYyzDbX7FTTx5hI/mobilebasic 